University of Nebraska - Lincoln

DigitalCommons@University of Nebraska - Lincoln

\title{
Effects of Leafy Spurge Infestation on Grassland Birds
}

Daniel M. Scheiman

Eastern Illinois University, dscheiman@audubon.org

Eric K. Bollinger

Eastern Illinois University

Douglas H. Johnson

USGS Northern Prairie Wildlife Research Center, Douglas_H_Johnson@usgs.gov

Follow this and additional works at: https://digitalcommons.unl.edu/usgsnpwrc

Part of the Other International and Area Studies Commons

Scheiman, Daniel M.; Bollinger, Eric K.; and Johnson, Douglas H., "Effects of Leafy Spurge Infestation on Grassland Birds" (2003). USGS Northern Prairie Wildlife Research Center. 230.

https://digitalcommons.unl.edu/usgsnpwrc/230

This Article is brought to you for free and open access by the US Geological Survey at DigitalCommons@University of Nebraska - Lincoln. It has been accepted for inclusion in USGS Northern Prairie Wildlife Research Center by an authorized administrator of DigitalCommons@University of Nebraska - Lincoln. 


\title{
EFFECTS OF LEAFY SPURGE INFESTATION ON GRASSLAND BIRDS
}

DANIEL M. SCHEIMAN, 1, 2 Department of Biological Sciences, Eastern Illinois University, Charleston, IL 61920, USA ERIC K. BOLLINGER, Department of Biological Sciences, Eastern Illinois University, Charleston, IL 61920, USA

DOUGLAS H. JOHNSON, U.S. Geological Survey, Northern Prairie Wildlife Research Center, 871137 th Street SE, Jamestown, ND 58401, USA

\begin{abstract}
Grassland bird populations are declining. Invasive plant species may be contributing to these declines by altering habitat quality. However, the effects of invasive plants on grassland birds are largely unknown. Leafy spurge (Euphorbia esula) is an exotic, invasive weed in the northern Great Plains. We examined the effects of leafy spurge infestation on densities of breeding birds, nest-site selection, and nest success in grasslands on the Sheyenne National Grassland (SNG), North Dakota, USA, 1999-2000. We categorized spurge-infested grasslands into 3 groups (low, medium, high), based on the area covered by spurge patches. We surveyed 75100 -m-radius circular points (25 in each group), and searched for nests in 6 16-ha plots ( 2 in each group). Grasshopper sparrow (Ammodramus savannarum) and savannah sparrow (Passerculus sandwichensis) densities were lower on high-spurge points than on lowand medium-spurge points. Bobolink (Dolichonyx oryzivorus) and western meadowlark (Sturnella neglecta) densities were not significantly different among spurge cover groups. Spurge cover did not appear to be an important factor in nest-site selection. However, western meadowlark nest success was positively associated with spurge cover. Vegetation structure is an important indicator of habitat quality and resource availability for grassland birds. Changes in vegetation structure caused by introduced plant species, such as spurge, can alter resource availability and hence affect bird community composition. Managers of spurge-infested grasslands should continue current spurge control measures to help prevent further declines in grassland habitat quality and grassland bird populations.
\end{abstract}

JOURNAL OF WILDLIFE MANAGEMENT 67(1):115-121

Key words: Ammodramus savannarum, bobolink, Dolichonyx oryzivorus, Euphorbia esula, grasshopper sparrow, grassland bird, invasive species, leafy spurge, North Dakota, Passerculus sandwichensis, savannah sparrow, Sheyenne National Grassland, Sturnella neglecta, vegetation structure, western meadowlark.

Grassland birds have shown more consistent population declines between 1966 and the 1990s than any other group of breeding birds in North America (Sauer et al. 2001). Although the virtual elimination of prairie habitat in the Midwest had a negative impact on grassland bird densities, this change occurred primarily before 1950 (Knopf 1994). Therefore, recent declines are likely due, at least in part, to factors reducing the quality of remaining grassland habitats. Exotic plant species reduce habitat quality and negatively affect biodiversity (Parker et al. 1993).

Leafy spurge is a perennial Eurasian forb that has become an invasive weed in the northern Great Plains (Belcher and Wilson 1989, Trammell and Butler 1995). Since introduction in North America in 1827 , leafy spurge has spread to 35 states and 5 Canadian provinces (U.S. Natural Resources Conservation Service 1999). In North Dakota, the epicenter of leafy spurge distribution, over 34,000 ha $(6 \%)$ of the state's untilled land were estimated to be infested in 1998 (Lym et al. 1998).

\footnotetext{
${ }^{1}$ E-mail: dms@fnr.purdue.edu

${ }^{2}$ Present address: Department of Forestry and Natural Resources, Forestry Building, 195 Marsteller Street, Purdue University, West Lafayette, IN 47907, USA.
}

Leafy spurge has the potential to alter plant community composition and structure by outcompeting native vegetation for available nutrients, light, and space (Bedunah 1992, Trammell and Butler 1995, Svedarsky and Van Amburg 1996). Leafy spurge prefers disturbed areas, such as grazed land, where it grows in dense patches $(200-2,800$ stems $/ \mathrm{m}^{2}$ ) in which native species are significantly reduced or eliminated (Selleck et al. 1962, Lym and Kirby 1987, Belcher and Wilson 1989, Wilson and Belcher 1989). Degradation of native plant communities and local extinction of preferred plant species caused by spurge and other exotics could theoretically reduce the carrying capacity of the landscape for wildlife (Trammell and Butler 1995, Svedarsky and Van Amburg 1996). However, specific effects of leafy spurge infestation on the abundance and productivity of wildlife, including grassland birds, remain largely unknown (Bedunah 1992).

The SNG encompasses 28,400 ha of federally owned and managed habitats in southeastern North Dakota and contains the state's largest native tallgrass prairie, as well as $\mathbf{4 0}$ federally sensitive plant and animal species (Svedarsky and Van Amburg 1996). Currently, over 4,400 ha (16\%) of the SNG are infested with leafy spurge (B. Stotts, U.S. Forest Service, Lisbon, North Dakota, personal communica- 
tion). Svedarsky and Van Amburg (1996:66) stated that this infestation "has greater potential than any other factor to significantly reduce the biodiversity of the SNG." Given the serious decline of many grassland bird populations, coupled with the rapid spread of leafy spurge (Leistritz et al. 1992), understanding bird-spurge associations is critically important, especially in grassland preserves like the SNG.

We examined the effects of leafy spurge infestation on breeding grassland birds in the SNG. Our objectives were to (1) compare the densities of breeding birds on grasslands among areas with 3 levels of spurge infestation, (2) determine whether the presence of spurge influences nest-site selection, and ( 3 ) determine whether the presence of spurge influences nest success. We hypothesized that breeding bird densities, nest-site selection, and nest success would be negatively affected by spurge infestation, assuming that spurge alters the taxonomic composition and habitat structure of grasslands that birds require for foraging and nesting (Belcher and Wilson 1989).

\section{STUDY SITE}

The SNG $\left(46^{\circ} 31^{\prime} \mathrm{N}, 97^{\circ} 16^{\prime} \mathrm{W}\right)$, located in Ransom and Richland counties in the Prairie Pothole Region of southeastern North Dakota, is divided into 2 units. We confined our study to the northern unit, which contains a matrix of federal $(27,242$ ha) and private (25,597 ha) land (Svedarsky and Van Amburg 1996). Approximately 55\% of the northern unit (both federal and private land) is covered by grassland (Svedarsky and Van Amburg 1996). We defined grassland as habitat dominated by big bluestem (Andropogon gerardii), little bluestem (Schizachyrium scoparium), Kentucky bluegrass (Poa pratensis), blue grama (Bouteloua gracilis), or switchgrass (Panicum virgatum).

Cattle (Bos taurus) grazing is a common management practice over most of the SNG (Svedarsky and Van Amburg 1996). Current control measures for leafy spurge include herbicide application, goat (Capra hircus) grazing, and biological control. More detailed discussions of the climate, soils, topography, and plant communities of the SNG and its surroundings were provided by Seiler and Barker (1985, 1987), and Hansen (1996).

\section{METHODS}

\section{Bird Densities and Point Vegetation}

In 1999, we established 60 100-m-radius circular points in grasslands. We assigned 20 points to each of 3 groups based on the percent of spurge coverage at the point: low, $0-20 \%$; medium, $20-60 \%$; and high, $>60 \%$. In 2000 , we established 5 additional points in each group. Randomly generated Universal Transverse Mercator coordinates were placed on all U.S. Geological Survey 7.5-min topographic maps that cover the SNG. We then located points in the field and categorized them by visual inspection. We accepted points if the area within $100 \mathrm{~m}$ was comprised of only 1 spurge cover type, and until each category was filled. The minimum distance between points was greater than the point radius to prevent double-counting birds.

We surveyed birds using the fixed-radius point count technique (Ralph et al. 1995). For this technique, we counted all birds, by species (and by sex for sexually dimorphic species), seen or heard from a fixed point in the center of the circle. For sexually monomorphic species, we noted whether individuals were detected visually or aurally. We estimated distances in 20-m intervals of birds within the point. Only birds detected within $100 \mathrm{~m}$ of the point were used in data analyses. We counted birds for $3 \mathrm{~min} /$ point, and each point was surveyed twice/season. Surveys occurred between 0500-1000 from late May to early July during 1999 and 2000. To minimize time-of-day bias, we alternated visits to a particular point between earlier and later halves of the survey time period. Points were not surveyed during heavy rains or when wind speeds exceeded $16 \mathrm{~km} / \mathrm{hr}$ (Martin and Conway 1994).

We chose the 4 most abundant grassland bird species (grasshopper sparrow, savannah sparrow, bobolink, western meadowlark) for analyses. We set $\alpha=0.10$ as the significance level for all statistical comparisons. We used MINITAB 13.32 (Minitab 2000) for all statistical tests unless otherwise noted.

Inherent differences in detectability exist between sexes of a species. Detectability can also depend on whether birds are vocalizing or silent (Mayfield 1981). Variation in detection probability causes bias in density estimates. For male and female bobolinks, and for visually and aurally detected individuals of the other 3 species, we used program DISTANCE 3.5 (Thomas et al. 1998) to obtain a correction factor, $\mathrm{h}(0)$, that adjusted the raw counts to account for detectability differences. DISTANCE 3.5 input consisted of an entry for each individual of each species and the 20-m distance interval within which it was detected for each visit to each survey point.

We based model selection for the detection function on the minimum Akaike's Information Criterion (AIC; Thomas et al. 1998). Potential models consisted of uniform or half-normal key functions, 
with cosine or simple polynomial series expansions. Counts were adjusted by $3-68 \%$ depending on the species. The magnitude of adjustment was similar between years for each species.

After adjusting for detectability, we averaged the 2 visits to each point to obtain 1 estimate of abundance for each species at each point during each year. We converted counts to a standardized unit of birds/100 ha. We tested for differential year effects using paired $t$-tests to compare bird densities in 1999 and 2000 for the 20 points surveyed in each spurge group. These paired $t$-tests indicated no significant year effect. Thus, we averaged years and used one-way analysis of variance (ANOVA) to determine whether differences existed in bird densities among spurge groups. Where a significant spurge effect was found, we used Tukey pairwise comparisons to determine which means were significantly different.

During June and July of each year, we measured vegetation cover and structure at each survey point. We established 4 vegetation sampling points within $100 \mathrm{~m}$ of each bird survey point in each of the 4 cardinal directions. At each vegetation sampling point, we assessed visual obstruction (in $\mathrm{dm}$ ), an index of the vertical density of the vegetation, using a Robel pole (Robel et al. 1970). We used a $0.5 \times$ 0.5-m Daubenmire frame (Daubenmire 1959) at each sampling point to estimate the percent of ground covered by leafy spurge, non-spurge forbs, grass, bunchgrass (displays a clumped growth habit, such as big bluestem), woody vegetation, bare ground, and litter. In addition, we counted the number of spurge stems, regardless of size, within the Daubenmire frame. Finally, we measured vegetation height (in $\mathrm{cm}$ ) and litter depth (in $\mathrm{mm}$ ) at each corner of the Daubenmire frame.

We averaged the 4 sampling points at each survey point to derive a measure of vegetation structure for each survey point. Number of spurge stems $/ \mathrm{m}^{2}$ and percent cover of spurge were highly correlated (Pearson correlation coefficient $[r]$ $=0.84)$, as were vegetation height and vertical density $(r=0.86)$. Therefore, we removed spurge stems $/ \mathrm{m}^{2}$ and vegetation height from subsequent analyses. We conducted a principal components analysis (PCA) of the vegetation variables to examine whether vegetation cover and structure differed among spurge groups. We analyzed the vegetation data pooled over years using the survey points in each spurge group as the sampling units. We then used 1-way ANOVA to determine whether differences existed in the first 2 PCA axes among spurge groups. Finally, we exam- ined the relationships between bird densities and the first 2 PCA axes using Pearson correlation.

\section{Nests and Nest Vegetation}

In 1999, we established 3 16-ha grassland plots, 1 at each level of spurge infestation. In 2000, we established 3 additional 16-ha plots, for a total of 2 plots at each level of infestation. We placed $25 \mathrm{PVC}$ conduits in a $500 \mathrm{~m} \times 500$-m grid at 100 -m intervals. We located grassland bird nests by observing adult behavior and by flushing birds with a stick while walking. When a nest was found, we checked it every 2-4 days until it was successful or failed. We defined nest success as fledging $\geq 1$ host young. We considered a nest abandoned if the adult was not detected for 3 consecutive visits and the nest and eggs were intact but had not hatched by the projected hatching date. Nests also were considered abandoned if we found nestlings dead but not damaged.

Once a nest was inactive, we gathered information about nest-site vegetation. We sampled nest vegetation, using procedures described earlier, with 1 set of measurements centered on the nest cup and 4 more sets located $0.5 \mathrm{~m}$ from the nest in each of the 4 cardinal directions. All 5 samples at each nest were averaged. For nests still active at the end of the study, we counted the number of spurge stems and estimated percent cover of spurge within 1 Daubenmire frame centered on the nest. We did not measure additional vegetation variables and vegetation in the 4 cardinal directions because we wanted to minimize disturbance to active nests.

To determine whether nests were placed in sites different from what was available in the area surrounding nests, we used paired $t$-tests to compare nest vegetation measurements to paired vegetation sampling sites. We selected a paired sampling site $30 \mathrm{~m}$ from the nest in a random direction and measured vegetation using the same procedure used for nests. To determine which vegetation variables affected nest success, we used stepwise multiple logistic regression (PROC LOGISTIC; SAS 1999) to find the best model. We then compared these models to the same models, with spurge forced in as a variable, to examine the influence spurge may have on nest success.

\section{RESULTS \\ Bird Densities and Point Vegetation}

Grasshopper sparrow densities were significantly lower on high-spurge points $(\bar{x}=28.4 \mathrm{birds} / 100$ ha, $\mathrm{SD}=26.2)$ than on low- $(\bar{x}=45.7$ birds $/ 100$ ha, $\mathrm{SD}=27.4)$ and medium-spurge $(\bar{x}=46.6, \mathrm{SD}=$ 
30.9) points $\left(F_{2,72}=3.03, P=0.04\right)$. Savannah sparrow densities also were significantly lower on highspurge points $(\bar{x}=12.1 \mathrm{birds} / 100 \mathrm{ha}, \mathrm{SD}=17.1)$ than on low- $(\bar{x}=26.7$ birds $/ 100 \mathrm{ha}, \mathrm{SD}=17.9)$ and medium-spurge $(\bar{x}=18.9$ birds $/ 100$ ha, $\mathrm{SD}=18.1)$ points $\left(F_{2,72}=4.25, P=0.02\right)$. Bobolink and western meadowlark densities did not differ significantly among spurge groups (bobolink: $F_{2,72}=0.95, P=$ 0.39 ; western meadowlark: $F_{2,72}=0.66, P=0.52$ ).

The PCA produced 4 principal components with eigenvalues $>1$, which collectively accounted for $73 \%$ of the variation in point vegetation. The first (PC1) and second (PC2) principal components accounted for $26 \%$ and $18 \%$ of the variation in the vegetation, respectively. Principal component 1 had high negative loadings for litter depth $(-0.50)$ and vertical density $(-0.57)$, and a high positive loading for bare ground cover (0.42). This component characterizes a gradient in vegetation density from points with a deep litter layer and dense vegetation to points with sparser structure and more bare ground. Principal component 2 had a high negative loading for grass cover $(-0.51)$, and a high positive loading for spurge cover $(0.61)$. This component represents increasing spurge infestation with a concomitant decrease in grass cover. Low- and medium-spurge points overlapped along the PC1 axis, whereas high-spurge points had significantly lower scores $\left(F_{2,72}=3.87, P=\right.$ 0.02 ). This indicates that low- and medium-spurge points were similar in terms of vegetation density while high-spurge points tended to have denser vegetation. Similarly, low- and medium-spurge points overlapped along the PC2 axis, whereas high-spurge points had significantly higher scores $\left(F_{2,72}=27.68, P<0.01\right)$, indicating high-spurge points had significantly higher levels of spurge infestation than low- and medium-spurge points. Grasshopper sparrow density was positively correlated with PC1 $(r=0.24)$. Savannah sparrow and bobolink densities were negatively correlated with PC2 ( $r=-0.30$ and -0.35 , respectively).

\section{Nests and Nest Vegetation}

We located 157 nests of 21 species. The 2 lowspurge plots combined and the 2 medium-spurge plots combined contained approximately the same number of nests ( $n=63$ and 57, respectively), and nesting species ( $n=24$ and 26 , respectively), whereas the 2 high-spurge plots combined held fewer nests $(n=37)$ and fewer nesting species $(n=15)$.

Grasshopper sparrow nests were surrounded by less non-spurge forb cover than paired sites (Table 1). Savannah sparrow nests were in areas of greater grass cover, less bare ground, and a deeper litter layer than paired sites (Table 1). Similarly, western meadowlarks nested in areas of less bare ground cover and a deeper litter layer than paired sites (Table 1). No significant differences were noted between nest sites and paired sites for bobolink nests (Table 1).

Grasshopper sparrow nest success was negatively associated with cover of woody vegetation and litter, litter depth, and vertical density (Table 2 ). Savannah sparrow nest success was positively associated with forb and grass cover (Table 2). Western meadowlark nest success showed a positive response to spurge cover (Table 2). Our ability to predict nest success with these models was fairly strong (\% concordance; Table 2 ). Bobolink nest success was unrelated to any of the measured vegetation variables. When spurge cover was forced into the models for grasshopper sparrows, savannah sparrows, and bobolinks, the predictive ability of the model changed by $<1 \%$ for grasshopper sparrows, increased by $7.4 \%$ for savannah sparrows, and was weak for bobolinks $(29.2 \%)$. These models indicate that spurge is probably not an important predictor of nest success for these species.

\section{DISCUSSION}

Observed patterns of bird densities on spurgeinfested grasslands may be linked to the vegetation structure of the survey points in accordance with known habitat preferences of these species. High-spurge points tended to contain denser vegetation than low- and medium-spurge points, possibly because spurge often grows in tall, dense patches (Lym and Kirby 1987, Wilson and Belcher 1989). Grasshopper sparrows typically select sparser, patchier, moderately open grasslands (Vickery 1996, Delisle and Savidge 1997). Similarly, savannah sparrows are associated with sites of low- to intermediate-vegetation density (Vickery 1996, Johnson and Igl 2001). In contrast, bobolinks prefer moderately dense vegetation, whereas western meadowlarks occur in a wide range of vegetation densities (Lanyon 1994, Martin and Gavin 1995, Johnson and Igl 2001).

In addition to breeding bird densities, we predicted that nest densities, nest-site selection, and nest success might be negatively influenced by spurge infestation. We predicted fewer nests on high-spurge plots, assuming spurge negatively alters the habitat structure that birds prefer for nesting. The numbers of nests and nesting species were lowest on high-spurge plots. However, 
Table 1. Vegetation cover and structure for nest sites and paired sampling sites for nests located in 6 16-ha plots in leafy spurgeinfested grasslands on the Sheyenne National Grassland, North Dakota, USA, 1999-2000. Paired sampling sites were located $30 \mathrm{~m}$ in a random direction from nest sites.

\begin{tabular}{|c|c|c|c|c|c|c|c|c|c|c|}
\hline \multirow[b]{3}{*}{ Vegetation variable } & \multicolumn{5}{|c|}{ Grasshopper sparrow $(n=36)$} & \multicolumn{5}{|c|}{ Savannah sparrow $(n=15)$} \\
\hline & \multicolumn{2}{|c|}{ Nest site } & \multicolumn{2}{|c|}{ Paired site } & \multirow[b]{2}{*}{ Paired $t$} & \multicolumn{2}{|c|}{ Nest site } & \multicolumn{2}{|c|}{ Paired site } & \multirow[b]{2}{*}{ Paired $t$} \\
\hline & $\bar{x}$ & SD & $\bar{x}$ & SD & & $\bar{x}$ & SD & $\bar{x}$ & SD & \\
\hline Spurge cover (\%) & 4.4 & 7.5 & 2.4 & 6.2 & 1.21 & 1.0 & 2.6 & 3.1 & 5.9 & -1.14 \\
\hline Non-spurge forb cover (\%) & 8.8 & 8.8 & 16.2 & 17.7 & $-2.12^{*}$ & 6.8 & 7.3 & 17.1 & 25.4 & -1.57 \\
\hline Grass cover $(\%)$ & 38.5 & 16.5 & 35.0 & 20.7 & 0.88 & 44.2 & 15.1 & 29.0 & 20.5 & $2.14^{\star}$ \\
\hline Bunchgrass cover (\%) & 4.4 & 10.2 & 1.7 & 5.5 & 1.32 & 7.4 & 14.7 & 8.3 & 20.8 & -0.13 \\
\hline Woody vegetation cover (\%) & 1.5 & 2.5 & 1.2 & 3.0 & 0.46 & 1.6 & 2.1 & 1.0 & 1.7 & 1.48 \\
\hline Bare ground cover $(\%)$ & 3.7 & 5.8 & 5.1 & 7.6 & -1.07 & 0.8 & 1.4 & 5.6 & 6.6 & $-2.73^{\star}$ \\
\hline Litter cover $(\%)$ & 36.8 & 12.0 & 36.3 & 21.1 & 0.11 & 37.7 & 16.6 & 35.9 & 19.9 & 0.35 \\
\hline Litter depth $(\mathrm{mm})$ & 23.5 & 18.4 & 26.4 & 73.9 & -0.24 & 27.4 & 18.7 & 16.0 & 17.3 & $2.18^{\star}$ \\
\hline \multirow[t]{3}{*}{ Vertical density (dm) } & 1.4 & 0.4 & 1.5 & 0.9 & -0.85 & 1.9 & 0.2 & 1.7 & 0.2 & 0.46 \\
\hline & \multicolumn{5}{|c|}{ Bobolink $(n=23)$} & \multicolumn{5}{|c|}{ Western meadowlark $(n=20)$} \\
\hline & \multicolumn{2}{|c|}{ Nest site } & \multicolumn{2}{|c|}{ Paired site } & & \multicolumn{2}{|c|}{ Nest site } & \multicolumn{2}{|c|}{ Paired site } & \\
\hline Vegetation variable & $\bar{x}$ & SD & $\bar{x}$ & SD & Paired $t$ & $\bar{x}$ & SD & $\bar{x}$ & SD & Paired $t$ \\
\hline Spurge cover (\%) & 5.6 & 11.8 & 7.7 & 12.8 & -0.85 & 5.6 & 9.6 & 5.3 & 7.2 & 0.13 \\
\hline Non-spurge forb cover (\%) & 13.0 & 20.0 & 17.1 & 25.2 & -0.94 & 5.9 & 5.9 & 11.3 & 16.7 & -1.32 \\
\hline Grass cover $(\%)$ & 41.7 & 14.3 & 35.0 & 20.4 & 1.51 & 43.2 & 16.9 & 38.4 & 21.0 & 1.06 \\
\hline Bunchgrass cover $(\%)$ & 3.0 & 7.9 & 4.6 & 14.4 & -0.46 & 1.3 & 3.9 & 0.8 & 3.4 & 0.42 \\
\hline Woody vegetation cover (\%) & 2.4 & 6.4 & 2.5 & 5.3 & -0.02 & 2.1 & 4.9 & 0.7 & 1.6 & 1.20 \\
\hline Bare ground cover $(\%)$ & 3.8 & 5.8 & 5.4 & 9.3 & -0.92 & 5.1 & 6.7 & 11.7 & 14.2 & $-2.28^{\star}$ \\
\hline Litter cover $(\%)$ & 29.8 & 14.1 & 27.7 & 17.2 & 0.52 & 36.0 & 11.9 & 31.0 & 18.9 & 1.20 \\
\hline Litter depth (mm) & 26.5 & 13.1 & 28.3 & 16.3 & -0.57 & 29.2 & 17.9 & 20.3 & 20.9 & $2.27^{\star}$ \\
\hline Vertical density (dm) & 2.2 & 1.2 & 2.5 & 1.3 & -1.14 & 1.9 & 0.7 & 1.7 & 1.0 & 0.57 \\
\hline
\end{tabular}

${ }^{*} P<0.10$.

nest-site selection was not influenced by spurge cover for the 4 focal bird species. In addition, nest success was not associated with spurge cover for grasshopper and savannah sparrows, and bobolinks. Surprisingly, western meadowlark nest success was positively associated with spurge cover. Meadowlarks may use spurge patches for nest concealment, although this relationship could have been an artifact of a small sample size ( $n=5$ successful and 15 unsuccessful nests). Nestsite selection and nest success were influenced by other vegetation variables, suggesting that structural features other than spurge were important in determining these processes.
Alterations to bird community composition caused by introduced plant species have been documented in a variety of habitats including mixedgrass prairie (Wilson and Belcher 1989, Sutter et al. 1995), arid grassland (Bock et al. 1986), freshwater wetland (Whitt et al. 1999, Hill 2000), riparian forest (Cohan et al. 1979), and upland deciduous forest (Schmidt and Whelan 1999). In each case, introduced plant species altered vegetation structure, thereby affecting the availability of resources (e.g., food and suitable nesting substrates) for birds. The effect of leafy spurge infestation on tallgrass prairie birds probably is another example of this apparently widespread phenomenon.

Table 2. Final models of grassland bird nest success as a function of vegetation variables using stepwise multiple logistic regression (PROC LOGISTIC, SAS 1999). Data were collected at nests located in 6 16-ha plots in leafy spurge-infested grasslands on the Sheyenne National Grassland, North Dakota, USA, 1999-2000.

\begin{tabular}{clccc}
\hline Species & \multicolumn{1}{c}{ Vegetation variable } & Estimate & SE & \% Concordance \\
\hline Grasshopper sparrow & Woody vegetation cover (\%) & -0.83 & 0.44 & 0.10 \\
& Litter cover (\%) & -0.23 & 0.08 & 91.9 \\
& Litter depth (mm) & -0.15 & 1.55 & 0.12 \\
Savannah sparrow & Vertical density (dm) & -2.81 & 0.05 & 8.9 \\
Western meadowlark & Non-spurge forb cover (\%) & 0.08 & 0.10 & 86.7 \\
\hline
\end{tabular}




\section{MANAGEMENT IMPLICATIONS}

Evidence from measurements of stem density suggests that if left unchecked, spurge will continue to spread across the SNG. The number of spurge stems $/ \mathrm{m}^{2}$ across survey points and plots ranged from 0-200 $(\bar{x}=16, \mathrm{SD}=29)$, which was similar to densities reported in previous studies in nearby grasslands (Lym and Kirby 1987, Svedarsky and Van Amburg 1996). However, spurge infestation on much of the SNG is relatively low compared to that reported by Selleck et al. (500-1,000 stems $\left./ \mathrm{m}^{2} ; 1962\right)$, which may be a result of persistent control measures carried out by the U.S. Forest Service and private landowners. If spurge is permitted to spread and further alter both the plant community composition and structure, resource abundance and availability will likely be altered as well (Wilson and Belcher 1989). We predict that some bird species, such as grasshopper and savannah sparrows, could continue to decline while others, such as the western meadowlark, may show habitat flexibility and use spurge patches for foraging and nesting.

\section{ACKNOWLEDGMENTS}

We thank J. F. Kelly, M. C. Becker, and 2 anonymous reviewers for comments on the manuscript. C. R. English, S. S. Patterson, and K. L. Phelps assisted in the data collection. We are grateful to B. Stotts and other staff at the U.S. Forest Service office in Lisbon, North Dakota, for permission to work on the Sheyenne National Grassland. Funding was provided by U.S. Geological Survey, Northern Prairie Wildlife Research Center; U.S. Agricultural Research Service, The Ecological Area-wide Management Leafy Spurge; and Eastern Illinois University.

\section{LITERATURE CITED}

BEDUNAH, D. J. 1992. The complex ecology of weeds, grazing and wildlife. Western Wildlands 18:6-11.

BelChER, J. W., AND S. D. Wilson. 1989. Leafy spurge and the species composition of a mixed-grass prairie. Journal of Range Management 42:172-175.

Bock, C. E., J. H. BoCK, K. L. JePSON, AND J. C. OrTEgA. 1986. Ecological effects of planting African lovegrasses in Arizona. National Geographic Research 2:456-463.

Cohan, D. R., B. W. ANderson, AND R. D. OHMART. 1979. Avian population responses to salt cedar along the lower Colorado River. Pages 371-382 in R. R. Johnson, and J. F. McCormick, editors. Strategies for protection and management of floodplain wetlands and other riparian ecosystems: proceedings of the symposium. U.S. Forest Service General Technical Report WO-12, Washington, D.C., USA.

DAUBENMIRE, R. F. 1959. A canopy coverage method of vegetational analysis. Northwest Science 33:43-64.
Delisle, J. M., AND J. A. SAvidGe. 1997. Avian use and vegetation characteristics of conservation reserve program fields. Journal of Wildlife Management 61:318-325.

HANSEN, K. 1996. The vegetation of the Sheyenne National Grassland: an ecological classification. U.S. Forest Service, Dakota Prairie Grasslands, Bismarck, North Dakota, USA.

HILL, J. D. 2000. Avian use of purple loosestrife (Lythrum salicaria) in southern Michigan wetland complexes. Thesis, Michigan State University, East Lansing, USA.

JoHnSON, D. H., AND L. D. IGL, series coordinators. 2001. Effects of management practices on grassland birds. Version 11APR2001. Northern Prairie Wildlife Research Center, Jamestown, North Dakota, USA. http://www.npwrc.usgs.gov/resource/literatr/grasbird/grasbird.htm.

KNOPF, F. L. 1994. Avian assemblages on altered grasslands. Studies in Avian Biology 15:247-257.

LANYON, W. E. 1994. Western meadowlark (Sturnella neglecta). In A. Poole, and F. Gill, editors. The birds of North America, no. 104. Academy of Natural Sciences, Philadelphia, Pennsylvania, USA, and The American Ornithologists' Union, Washington, D.C., USA.

Leistritz, F. L., F. Thompson, AND J. A. Leitch. 1992. Economic impact of leafy spurge (Euphorbia esula) in North Dakota. Weed Science 40:275-280.

LYM, R. G., AND D. R. KIRBY. 1987. Cattle foraging behavior in leafy spurge (Euphorbia esula)-infested rangeland. Weed Technology 1:314-318.

—, C. G. Messersmith, AND R. Zollinger. 1998. Leafy spurge identification and control. North Dakota State University Extension Service Circular W-765 (Revised), Fargo, USA.

MARTIN, S. G., AND T. A. GAVIN. 1995. Bobolink (Dolichonyx oryzivorus). In A. Poole, and F. Gill, editors. The birds of North America, no. 176. Academy of Natural Sciences, Philadelphia, Pennsylvania, USA, and The American Ornithologists' Union, Washington, D.C., USA.

MARTIN, T. E., AND C. J. CoNWAY. 1994. BBIRD field protocol: breeding biology research and monitoring database. Montana Cooperative Wildlife Research Unit, University of Montana, Missoula, USA.

MAYFIELD. H. F. 1981. Problems in estimating population size through counts of singing males. Studies in Avian Biology 6:220-224.

MinitaB. 2000. Minitab for Windows, Release 13.32. Minitab, State College, Pennsylvania, USA.

PARKer, I. M., S. K. MERTENS, AND D. W. SCHEMSKe. 1993. Distribution of seven native and two exotic plants in a tallgrass prairie in southeastern Wisconsin: the importance of human disturbance. American Midland Naturalist 130:43-55.

RAlPH, C. J., J. R. SAUER, AND S. DRoege, editors. 1995. Monitoring bird populations by point counts. U.S. Forest Service General Technical Report PSW-GTR-149.

Robel, R. J., J. N. BRiggS, A. D. DAYTON, AND L. C. HulBERT. 1970. Relationships between visual obstruction measurements and weight of grassland vegetation. Journal of Range Management 23:295-297.

SAS INSTITUTE. 1999. The SAS System for Windows, Release 8.02, TS Level 02M0. SAS Institute, Cary, North Carolina, USA.

Sauer, J. R., J. E. Hines, and J. Fallon. 2001. The North American Breeding Bird Survey, results and analysis 1966-2000. Version 2001.2. Patuxent Wildlife Research 
Center, Laurel, Maryland, USA. http://www.mbr.nbs. gov/bbs/bbs.html.

SCHMIDT, K. A., AND C. J. WHELAN. 1999. Effects of exotic Lonicera and Rhamnus on songbird nest predation. Conservation Biology 13:1502-1506.

SeILER, G. J., AND W. T. BARKER. 1985. Vascular flora of Ransom, Richland, and Sargent counties, North Dakota. Prairie Naturalist 17:193-240. AND 1 1987. Life-forms and geographic affinities of the southeastern North Dakota flora Prairie Naturalist 19:77-92.

Selleck, G. W., R. T. Coupland, ANd C. Frankton. 1962. Leafy spurge in Saskatchewan. Ecological Monographs 32:1-29.

SuTter, G. C., T. Troupe, AND M. Forbes. 1995. Abundance of Baird's sparrows, Ammodramus bairdii, in native prairie and introduced vegetation. Ecoscience 2:344-348.

SvEDARSKY, D., AND G. VAN AMBURG. 1996. Integrated management of the greater prairie chicken and livestock on the Sheyenne National Grassland. North Dakota Game and Fish Department, Bismarck, USA. Thomas, L., J. L. LaAKe, J. F. Derry, S. T. Buckland, D. L. Borchers, D. R. ANderson, K. P. Burnham, S. StrindBerG, S. L. Hedley, M. L. Burt, F. MarQues, J. H. Pollard, AND R. M. Fewster. 1998. Distance 3.5.
Research Unit for Wildlife Population Assessment, University of St. Andrews, United Kingdom.

Trammell, M. A., AND J. L. ButLer. 1995. Effects of exotic plants on native ungulate use of habitat. Journal of Wildlife Management 59:808-816.

U.S. Natural Resources Conservation Service. 1999. The PLANTS database. National Plant Database Center, Baton Rouge, Louisiana, USA. http://plants.usda.gov. VICKERY, P. D. 1996. Grasshopper sparrow (Ammodramus savannarum). In A. Poole, and F. Gill, editors. The birds of North America, no. 239. Academy of Natural Sciences, Philadelphia, Pennsylvania, USA, and The American Ornithologists' Union, Washington, D.C., USA.

Whitt, M. B., H. H. Prince, ANd R. R. Cox, JR. 1999. Avian use of purple loosestrife dominated habitat relative to other vegetation types in a Lake Huron wetland complex. Wilson Bulletin 111:105-114.

Wilson, S. D., AND J. W. BELCHER. 1989. Plant and bird communities of native and introduced Eurasian vegetation in Manitoba, Canada. Conservation Biology 3:39-44.

Received 8 March 2002.

Accepted 9 October 2002.

Associate Editor: Kelly. 